\title{
Skleroderma pada Anak
}

\author{
Melissa Gandi, Qatrah D. Seprida, Tina W. Wisesa, * Zakiudin Munasir** \\ * Departemen Kulit Kelamin Universitas Indonesia, RS Dr. Cipto Mangunkusumo Jakarta \\ ** Divisi Alergi Imunologi Departemen Ilmu Kesehatan Anak Universitas Indonesia, RS Dr. Cipto \\ Mangunkusumo Jakarta
}

\begin{abstract}
Dilaporkan seorang anak perempuan, N, usia 4 tahun 5 bulan, dengan diagnosis skleroderma lokal tipe morfea generalisata. Etiologi dan patogenesis penyakit ini belum jelas. Pada pemeriksaan fisis didapatkan makula hipopigmentasi multipel, plakat hiperpigmentasi difus yang sklerotik, fleksi kontraktur jari tangan dan kaki serta atrofi kulit punggung tangan dan kaki. Tidak ada keterlibatan organ dalam. Pemeriksaan histopatologis menunjukkan penebalan kolagen di dermis dan tidak tampak adneksa kulit. Pengobatan terdiri dari krim pelembab, obat antifibrotik dan fisioterapi. Pasien membaik dengan pemberian krim urea $10 \%$ dan D-penisilamin. Prognosis baik karena morfea generalisata akan mengalami resolusi spontan dalam 3-5 tahun, meskipun dapat menyebabkan kecacatan permanen berupa fleksi kontraktur residual, hiperpigmentasi dan atrofi kulit (Sari Pediatri 2008; 9(6):398-405).
\end{abstract}

Kata kunci: skleroderma, morfea generalisata, plakat hiperpigmentasi sklerotik

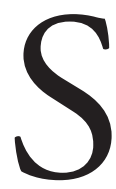

kleroderma merupakan penyakit autoimun jaringan ikat yang ditandai dengan penumpukan kolagen berlebihan di sekitar pembuluh darah kapiler dan jaringan yang terkena, misalnya kulit, paru-paru, jantung, esofagus dan ginjal. ${ }^{1}$ Kata skleroderma berarti "kulit keras", ${ }^{2-5}$ dan pengerasan kulit ini merupakan gejala utama pada semua tipe skleroderma. ${ }^{3,4,6}$

Penyakit ini bersifat kronis, belum diketahui penyebabnya serta jarang terjadi pada anak. ${ }^{3,4,7}$ Data dari rekam medik di Departemen Ilmu Kesehatan

\section{Alamat korespondensi}

Dr. Zakiudin Munasir, Sp.A(K), Divisi Alergi Imunologi Departemen Ilmu Kesehatan Anak FKUI-RSCM, Jl. Salemba 6, Jakarta 10430. Telp. 021-3161144, Fax. 021-3913982.
Anak RS Dr. Cipto Mangunkusumo (IKA-RSCM) sejak 1986 sampai Juni 2006 hanya didapatkan 6 kasus skleroderma. Di Amerika Serikat diperkirakan terdapat 19 kasus per 1 juta orang dewasa per tahun, ${ }^{1,8,9}$ dan kurang dari $10 \%$ terjadi pada anak. ${ }^{7}$ Skleroderma diklasifikasikan menjadi skleroderma lokal (SL) bila kelainan terbatas pada kulit dan jaringan subdermis, dan disebut skleroderma sistemik (SS) bila disertai keterlibatan organ dalam..$^{7,10,11}$ Skleroderma pada anak lebih sering bersifat lokal. ${ }^{3,7,12}$ Usia rerata timbulnya SL pada anak 7,9 tahun. $^{12}$

\section{Kasus}

Seorang anak perempuan, N, usia 4 tahun 5 bulan, 
dirujuk ke Poliklinik Alergi Imunologi Departemen IKA-RSCM oleh Departemen Ilmu Kesehatan Kulit dan Kelamin RSCM Divisi Dermatologi Anak dengan diagnosis skleroderma untuk evaluasi keterlibatan sistemik. Enam bulan sebelum datang ke RSCM, tampak bercak merah pada kulit perut kanan berbentuk koin ukuran $2 \mathrm{~cm}$, gatal dan tidak nyeri. Sebulan kemudian timbul bercak putih ukuran 1-2 cm di kedua lengan atas dan bahu yang menyebar ke perut, tungkai serta jari tangan dan kaki yang makin kasar dan menebal. Pasien tiga kali berobat ke dokter kulit diobati sebagai infeksi jamur, namun tidak ada perbaikan dan bercak berubah menjadi kehitaman dan mengeras.

Hasil biopsi kulit menunjukkan epidermis normal, melanin di beberapa tempat di ujung rete ridges bertambah dan sebagian ada yang berkurang, kolagen dermis menebal dan adneksa tidak tampak (Gambar 1), sesuai dengan skleroderma. Pasien diberi krim pelembab urea $10 \%$ dioleskan 3 kali sehari, sirup hidroksizin 3 x 15 mg dan D-penisilamin (Cuprimine ${ }^{\circledR}$ ) per oral $2 \times 2 \mathrm{mg}(0,2 \mathrm{mg} / \mathrm{kgBB} / \mathrm{hari})$.

Pemeriksaan fisis di poliklinik Alergi Imunologi Departemen Ilmu Kesehatan Anak rumah sakit Dr. Cipto Mangunkusumo Jakarta didapatkan keadaan umum baik dan kompos mentis. Berat badan $20 \mathrm{~kg}$ $\left(\mathrm{P}_{75-90} \mathrm{NCHS} 2000\right)$, panjang badan $100 \mathrm{~cm}\left(\mathrm{P}_{25-50}\right.$ NCHS 2000). Pada pemeriksaan kulit didapatkan makula hipopigmentasi multipel ukuran lentikular sampai numular, berbatas tegas pada belakang leher dan bokong kanan. Pada kiri dan kanan dada, perut, punggung, ketiak, ekstremitas atas dan bawah, lipat paha dan lutut, serta punggung tangan dan kaki terdapat makula hiperpigmentasi difus berwarna coklat kehitaman, multipel ukuran numular sampai plakat serta tampak skuama kasar dan kering (Gambar 2). Kulit menebal, ketat, mengeras dan sklerosis, terutama di perut kanan serta punggung tangan dan kaki bilateral (Gambar 3). Pada lesi kulit yang sklerosis tidak tumbuh rambut, tidak berkeringat dan beberapa lesi tampak mengkilat. Tidak tampak lesi kulit maupun telangiektasis pada wajah dan kuku. Pada kepala dan wajah tidak tampak deformitas. Konjungtiva tidak pucat dan sklera tidak ikterik. Mulut dapat dibuka lebar. Telinga, hidung dan tenggorok serta jantung, paru dan perut tidak ada kelainan. Kulit pada punggung tangan dan kaki bilateral tampak atrofi. Posisi jari tangan kanan II, III, V dan jari tangan kiri V fleksi kontraktur ringan, tidak tampak sianosis dan tidak nyeri (Gambar 4). Metatarsal ibu jari kaki kiri abduksi (Gambar 5). Pergerakan sendi pergelangan kaki kiri dan kanan agak terbatas.

Pemeriksaan penunjang menunjukkan darah perifer lengkap (DPL) dalam batas normal, tidak ada eosinofilia, namun laju endap darah (LED) meningkat $45 \mathrm{~mm} /$ jam. Fungsi hati dan ginjal normal. Hasil pemeriksaan imunologi ANA positif 1/320 dan anti-dsDNA 704,3 $\mathrm{IU} / \mathrm{mL}(\mathrm{N}:=100 \mathrm{IU} / \mathrm{mL})$. Terdapat peningkatan kadar imunoglobulin (Ig) G $2454 \mathrm{mg} / \mathrm{dL}$ (N: 741-1851 mg/ dL), IgA $143 \mathrm{mg} / \mathrm{dL}(\mathrm{N}: 40-74 \mathrm{mg} / \mathrm{dL})$ dan IgM 300 $\mathrm{mg} / \mathrm{dL}$ (N: 78-150 mg/dL), sedangkan Ig E 17,5 IU/ $\mathrm{mL}$ normal (N: 0-170 IU/mL). Kadar C3 dan C4 normal, masing-masing $120 \mathrm{mg} \%(\mathrm{~N}: 55-120 \mathrm{mg} \%)$ dan $27 \mathrm{mg} \%$ (N: 20-50 mg\%). Hasil tersebut cenderung menunjukkan penyakit autoimun yang sudah lama dan bukan penyakit alergi. Hasil foto toraks, elektrokardiografi dan ekokardiografi normal. Hasil foto Röntgen lengan, siku, lutut, tangan dan kaki kiri kanan, tidak tampak kalsinosis maupun osteoporosis dan sendi tidak menyempit.

Berdasarkan data yang ditemukan serta belum ada gejala dan tanda kelainan sistemik, maka diagnosis ditegakkan sebagai skleroderma lokal tipe morfea generalisata. Pengobatan D-penisilamin, krim urea $10 \%$ diteruskan, ditambah setirizin $2 \times 2,5 \mathrm{mg}$ untuk mengatasi gatal dan multivitamin antioksidan Betafort ${ }^{\circledR} 1 \times 5 \mathrm{ml}$, serta terapi okupasi dan fisioterapi 2 kali seminggu dan program hidroterapi 1 kali seminggu untuk meningkatkan kapasitas fungsional persendian dan daya tahan tubuh. Pasien dianjurkan memakai splints tangan dan sepatu khusus untuk mencegah deformitas lebih lanjut. Tiga bulan setelah terapi tidak timbul lesi baru, lesi sklerosis di kulit makin menipis dan lebih lembut, makula hiperpigmentasi memudar menjadi coklat muda. Lingkup gerak sendi tangan, kaki dan jari makin membaik. Tidak ada gangguan saluran cerna, paru-paru maupun jantung. Hasil pemantauan pemeriksaan darah sebulan sekali menunjukkan tidak ada efek samping obat Dpenisilamin. Orangtua dan pasien diberi edukasi tentang penyakit, tata laksana, prognosis serta pemantauan efek samping obat dan keterlibatan sistemik yang akan dilakukan secara berkala.

\section{Diskusi}

Skleroderma merupakan penyakit jaringan ikat yang melibatkan kulit, pembuluh darah dan sistem imun. ${ }^{2}$ 


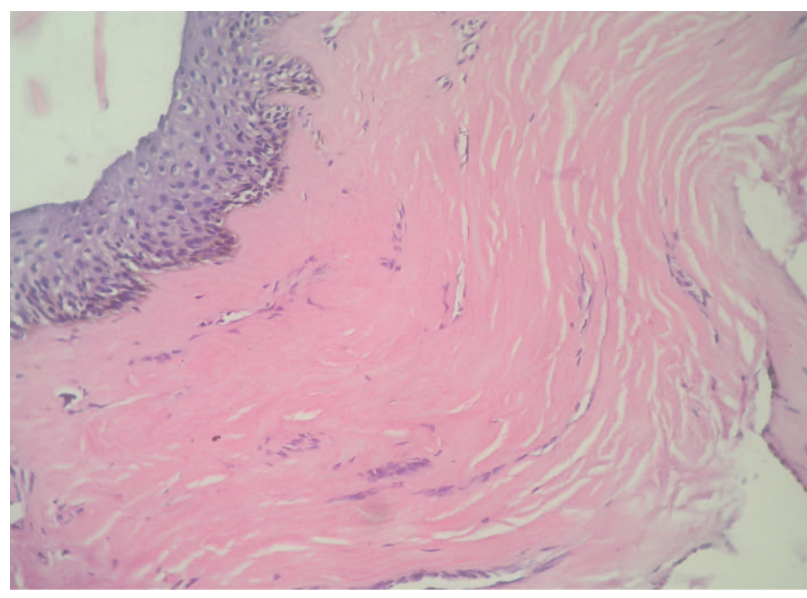

Gambar 1. Kolagen dermis menebal

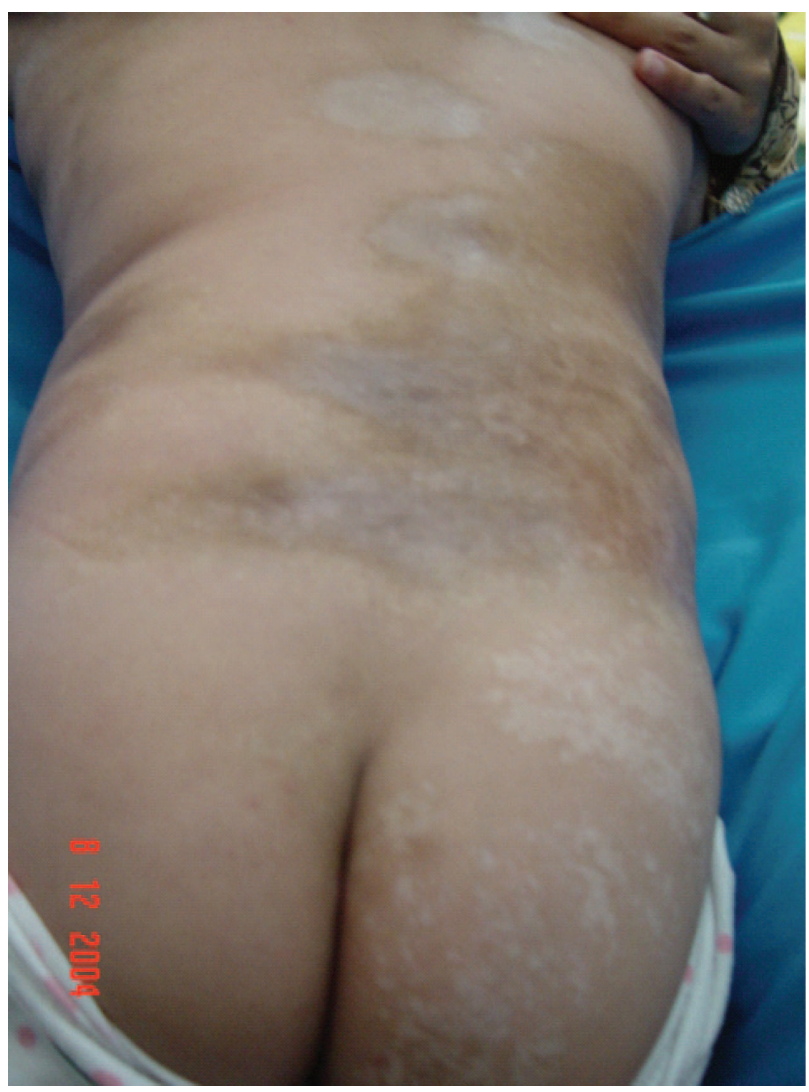

Gambar 2. Plakat hiperpigmentasi pada punggung dan makula hipopigmentasi pada bokong

Lebih sering terjadi pada anak perempuan dengan perbandingan 3:1, ${ }^{7}$ dapat terjadi pada semua ras dan etnis, dan dapat bersifat familial walaupun sangat jarang. ${ }^{13}$ Pasien adalah anak perempuan berusia 4 tahun saat onset penyakit dimulai dan tidak mem-

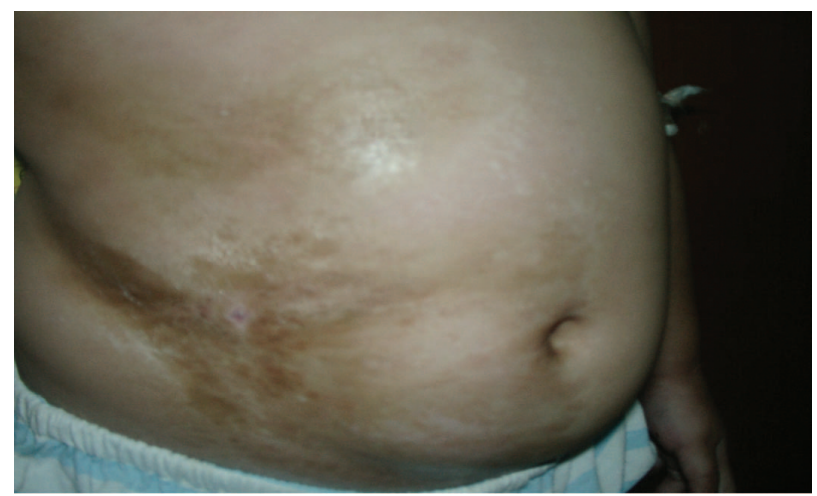

Gambar 3. Kulit menebal dan sklerosis

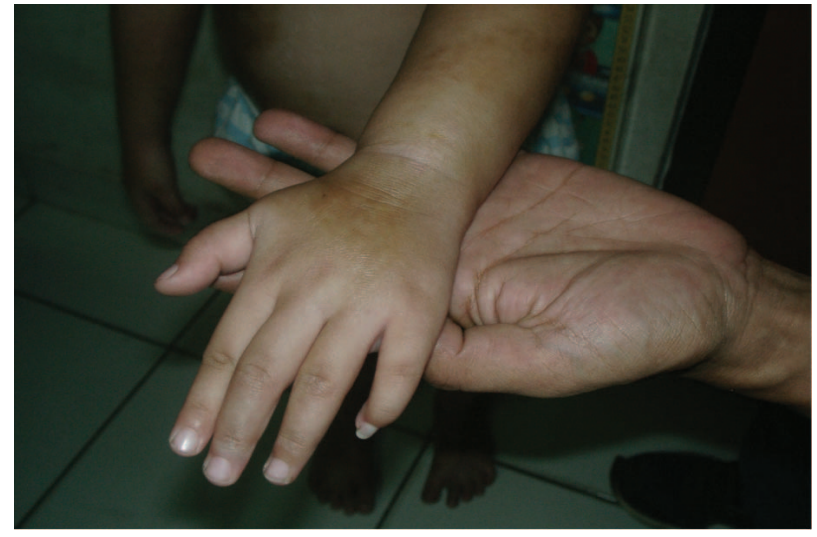

Gambar 4. Fleksi kontraktur jari ke V tangan kiri

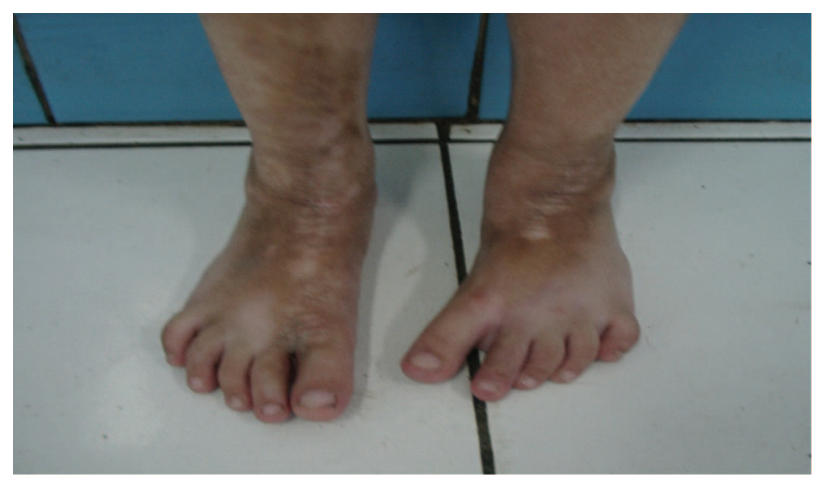

Gambar 5. Kulit atrofi, ibu jari abduksi

punyai riwayat keluarga dengan kelainan kulit seperti skleroderma.

Etiologi pasti hingga kini masih belum jelas, ${ }^{7,12,14}$ namun proses autoimun, vaskulopati dan abnormalitas matriks ekstraselular (fibroblas) dipikirkan sebagai 
mekanisme patogenesisnya. ${ }^{3,4,15}$ Banyak faktor yang diduga menjadi pencetus skleroderma, antara lain autoimun, keturunan, faktor lingkungan, infeksi, obatobatan (bleomisin, bromokriptin), bahan kimia (benzen, toluen), trauma fisik dan stres psikologis yang dapat merusak jaringan vaskular dan menghasilkan reaksi skleroderma. ${ }^{12}$ Pada pasien ini tidak terdapat faktor pencetus tersebut.

Berdasarkan luas dan kedalaman lesi, secara garis besar SL atau disebut morfea terbagi atas 5 tipe yaitu morfea plakat, morfea generalisata, morfea bulosa, morfea linear dan morfea dalam. ${ }^{12}$ Morfea linear merupakan tipe yang paling banyak ditemukan pada populasi anak dan remaja. ${ }^{12}$ Skleroderma sistemik dibagi menjadi 3 tipe yaitu sklerosis sistemik kutaneus difus (SSKD) dan sklerosis sistemik kutaneus terbatas (SSKT) serta sindrom overlap (sklerodermatomyositis dan penyakit jaringan ikat campuran). ${ }^{7}$

Manifestasi klinis saat awal tidak selalu jelas. Morfea plakat awalnya berupa bercak merah pada kulit yang makin menebal dan mengeras, berbentuk oval, bagian tengahnya berwarna kuning gading dengan tepi keunguan (Gambar 6). 2,5,12 Semakin lama semakin mengkilat dan terasa ketat. ${ }^{3,4,7}$ Jumlahnya bisa satu atau lebih dengan diameter $1-30 \mathrm{~cm} .^{5,14}$ Bercak ini tidak berkeringat maupun berambut, ${ }^{4,5,12}$ gatal dan tidak nyeri. ${ }^{4}$ Tipe morfea generalisata berupa plakat besar, multipel dengan indurasi dan hiperpigmentasi, umumnya bilateral pada kulit dada, punggung, perut, bokong dan ekstremitas. ${ }^{12}$ Perjalanan alamiah penyakit yang biasa terjadi adalah fase inflamasi, progresivitas lesi, fase stabilisasi dan terakhir pelunakan kulit dan perbaikan pigmentasi, namun bisa meninggalkan cacat berupa hiperpigmentasi dan atrofi kulit maupun otot., ${ }^{42,14}$ Skleroderma pada kasus ini digolongkan dalam tipe morfea generalisata. Hal ini berdasarkan kelainan kulit yang luas dengan bercak indurasi multipel dan hiperpigmentasi, tanpa adanya keterlibatan sistemik. Lesi pada morfea linear berupa plakat sklerotik berbentuk garis lurus, unilateral pada 8595\% kasus (Gambar 7). ${ }^{4,5,12}$ Lesi bisa meluas ke dermis, subkutis, otot dan tulang, sehingga menganggu fungsi dan kosmetis. ${ }^{4,11,12}$ Lesi sering timbul pada ekstremitas bawah, lalu diikuti ekstremitas atas, frontal kepala (disebut en coup de sabre seperti luka sambaran pedang, Gambar 8), ,,12,14 toraks anterior dan bokong., ${ }^{4,5,12}$

Sklerosis sistemik kutaneus difus mengenai wajah, badan dan ekstremitas proksimal, dengan perubahan kulit yang progresif, disertai keterlibatan sistemik pada awal penyakit. Perubahan yang khas dimulai dengan sklerotik pada kulit dorsal permukaan jari (acrosclerosis) bilateral simetris (Gambar 9), wajah tanpa ekspresi, dengan kerut sirkumoral dan berkurangnya pembukaan mulut yang bisa dipakai sebagai petunjuk utama diagnosis (Gambar 10). ${ }^{3}$ Sklerosis sistemik kutaneus terbatas (Gambar 11-14) disebut sebagai CREST syndrome (Calcinosis cutis, Raynaud's phenomenon, esophageal dysfunction, sclerodactily, telangiectases). ${ }^{3,5,6}$ Gejala Raynaud's phenomenon berupa keluhan jari tangan yang berubah warna secara berurutan menjadi pucat, biru dan merah bila terkena dingin atau stres. Telangiektasis tampak sebagai bintik kecil merah pada tangan dan wajah karena dilatasi kapiler. ${ }^{2,6}$

Diagnosis skleroderma ditegakkan berdasarkan anamnesis, pemeriksaan fisis dan dipastikan dengan pemeriksaan histopatologis. ${ }^{6,12,14}$ Pada skleroderma sesudah fase inflamasi akan diikuti oleh penipisan epidermis, penggantian jaringan subkutan dengan jaringan ikat hialin dan hilangnya adneksa kulit., ${ }^{3,12,16}$

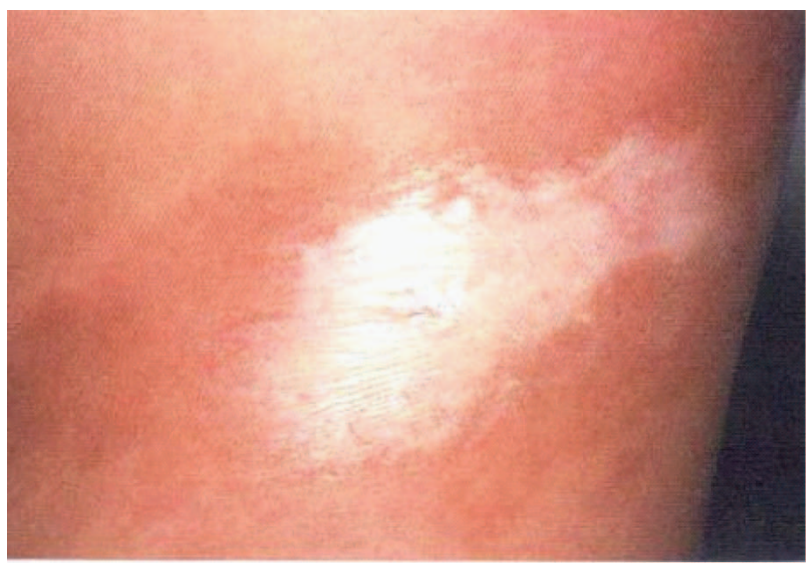

Gambar 6. Morfea plakat

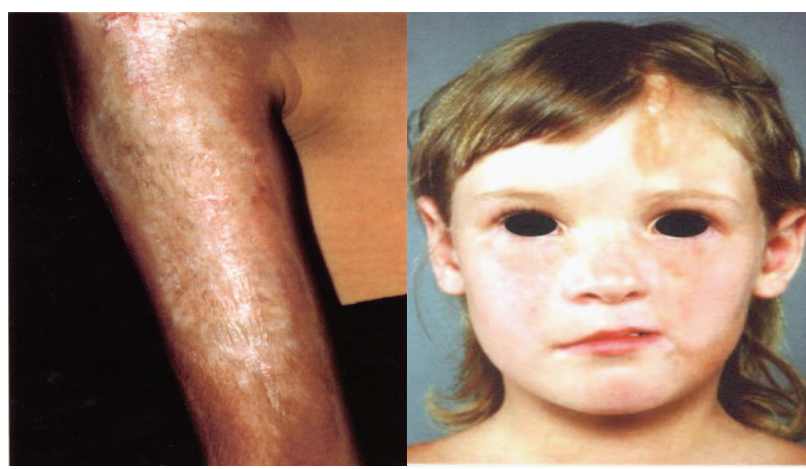

Gambar 7. Morfea linear

Gambar 8. En coup de sabre 


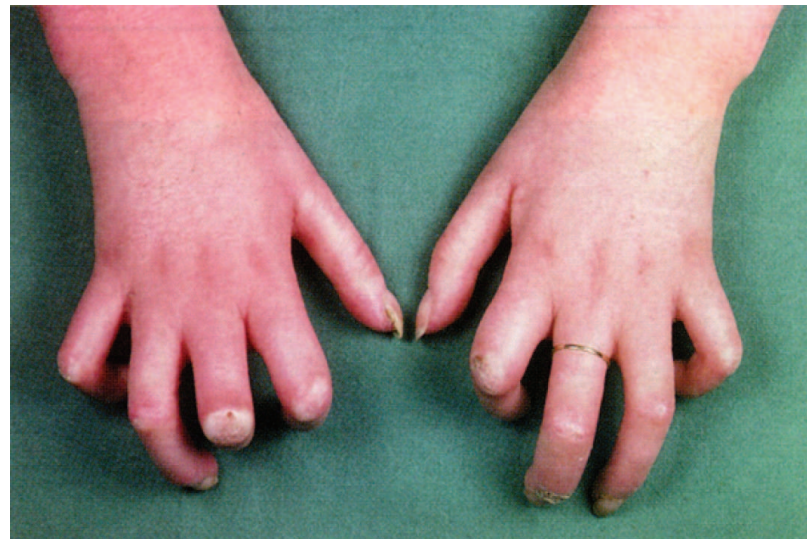

Gambar 9. Acro-sclerosis

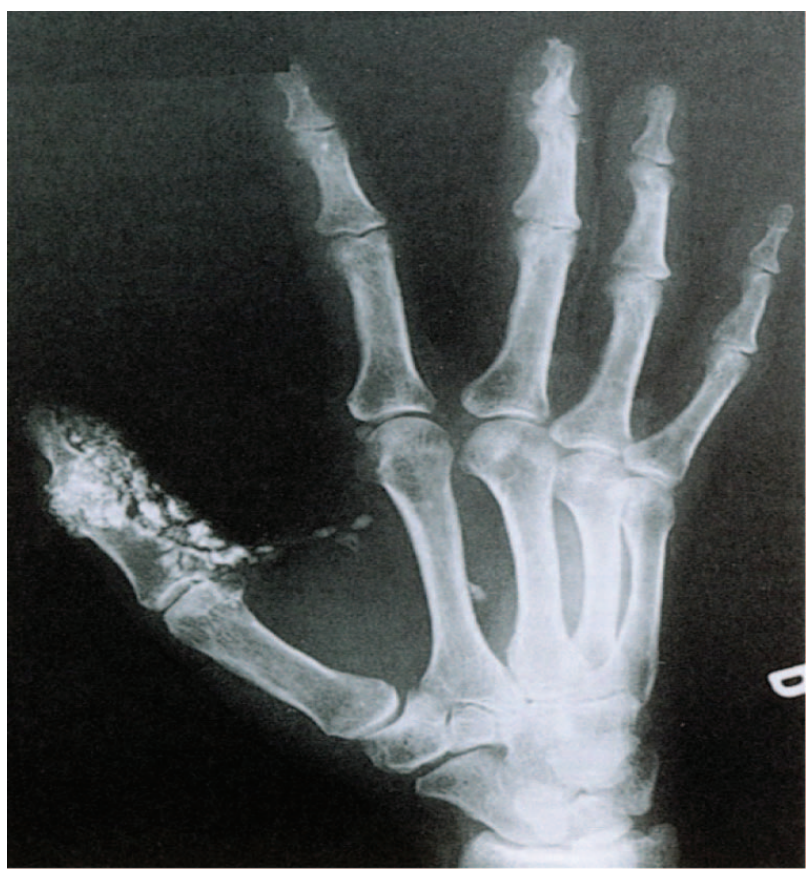

Gambar 11. Calcinosis

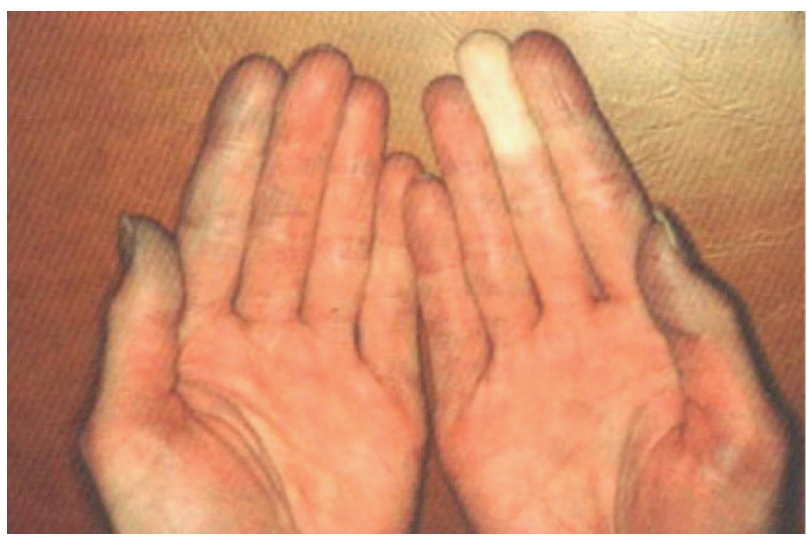

Gambar 12. Raynaud's phenomenon

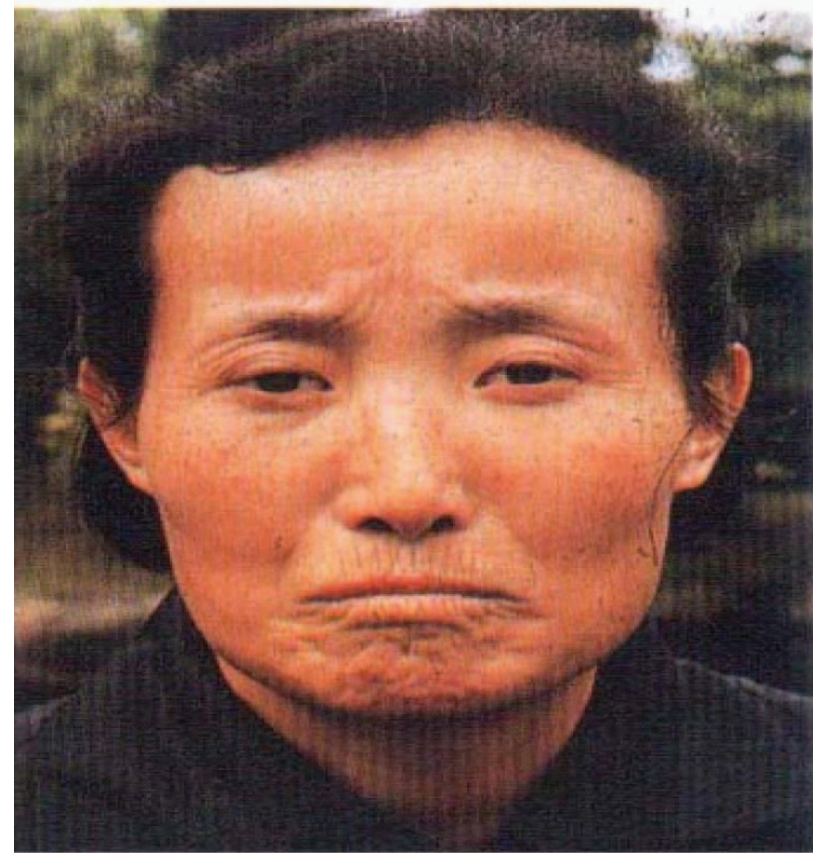

Gambar 10. Sklerosis sistemik kutaneus difus

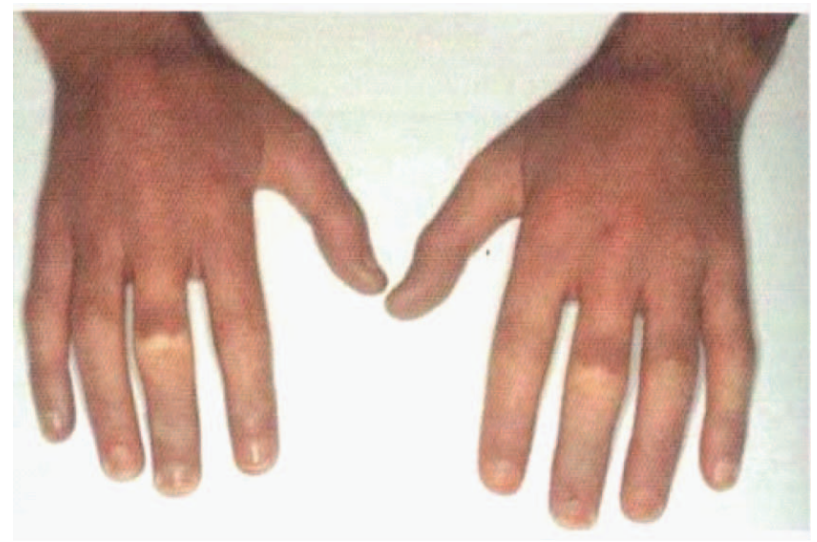

Gambar 13. Sclerodactily

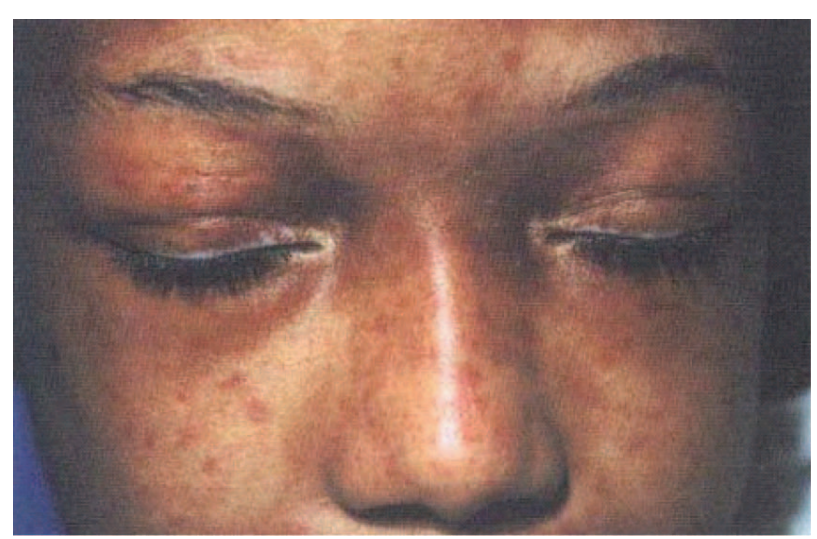

Gambar 14. Telangiektasis 
Pada stadium lanjut, keseluruhan dermis digantikan dengan serabut kolagen padat, ${ }^{12}$ pembuluh darah menebal dan lumen pembuluh darah menyempit. ${ }^{3}$ Pada pasien ini, gambaran histopatologis menunjukkan penebalan kolagen dermis dan tidak tampak adneksa kulit, ini merupakan gambaran fase lanjut dari skleroderma.

Secara umum, tidak ada pemeriksaan laboratorium yang dapat menegakkan diagnosis skleroderma. ${ }^{12,17}$ Pemeriksaan DPL pada SL umumnya normal, ${ }^{15}$ walaupun eosinofilia dapat terjadi pada $15 \%$ kasus. ${ }^{3,11}$ Laju Endap Darah umumnya normal, bisa meningkat bila ada peradangan aktif. ${ }^{11}$ Pada pasien SL imunoglobulin meningkat, ANA positif pada 23\%-73\% kasus dan rheumatoid factor (RF) positif pada $25 \%$ $40 \%$ kasus. ${ }^{4,12}$ Anti-dsDNA umumnya tinggi ${ }^{4}$ dan kadar imunoglobulin serum meningkat lebih sering pada pasien dengan penyakit yang aktif dan meluas disertai kontraktur sendi. ${ }^{4,11,12}$ Pada pasien ini pemeriksaan ANA positif, anti-dsDNA serta IgG, IgA dan IgM meningkat. Hasil pemeriksaan imunologis menunjukkan penyakit autoimun yang biasanya lebih spesifik pada lupus, namun pada pasien ini tidak ditemukan gejala yang sesuai dengan lupus. Jadi peningkatan tersebut lebih disebabkan karena lesi kulit yang luas disertai kontraktur sendi.

Pada pasien SL sangat penting untuk menyingkirkan SS walaupun sangat jarang pada anak., ${ }^{4,11}$ Untuk menyingkirkan kemungkinan itu, pada pasien ini dilakukan beberapa pemeriksaan penunjang. Hasil pemeriksaan ekokardiografi tidak menunjukkan adanya hipertensi pulmonal. Pada foto toraks tidak tampak fibrosis. ${ }^{8,11}$ Pasien ini idealnya menjalani pemeriksaan tes fungsi paru (TFP) dan HRCT scans dada. ${ }^{1,11}$ Tes fungsi paru berupa pengukuran kapasitas difusi karbon monoksida yang cukup sensitif untuk mengetahui kemungkinan adanya fibrosis paru, sedangkan HRCT scans dada mampu mendeteksi proses inflamasi dini berupa alveolitis yang mendahului proses fibrosis. ${ }^{6,9,18}$ Namun pasien ini masih berusia 4 tahun sehingga belum dapat menjalani TFP dengan alat yang tersedia di RSCM, dan karena keterbatasan dana maka HRCT scans dada baru akan dilakukan bila timbul keluhan batuk lama atau sesak. Hasil foto Röntgen ekstremitas tidak tampak kalsinosis, tidak terdapat gejala Raynaud's phenomenon, serta tidak ada gangguan saluran cerna. Pada pasien dengan kecurigaan kelainan sistemik perlu dilakukan pemeriksaan antibodi khusus yaitu anti-topoisomerase 1 antibody
(anti-Scl-70) yang spesifik untuk SSKD, ${ }^{8,9}$ dan anticentromere antibody (ACA) untuk SSKT. ${ }^{17}$ Namun kedua pemeriksaan tersebut tidak perlu dilakukan karena belum ada gejala dan tanda kelainan organ dalam, maka sampai saat ini belum ditemukan keterlibatan sistemik pada pasien ini.

Tata laksana skleroderma sulit karena etiologinya belum jelas. ${ }^{19,20}$ Terapi farmakologis (Tabel 1) ditujukan pada patogenesisnya dengan pemberian terapi vaskular untuk memperbaiki sirkulasi perifer, imunosupresan untuk mencegah sintesis dan pelepasan sitokin, dan obat penghambat fibrosis. ${ }^{19}$ Terapi nonfarmakologis berupa psikoterapi, fisioterapi, dan terapi bedah yang diharapkan dapat memperbaiki kualitas hidup pasien. ${ }^{20}$

Tata laksana utama pada morfea adalah terapi topikal seperti krim pelembab, kortikosteroid atau kalsipotrien topikal. ${ }^{12}$ Kortikosteroid topikal (hidrokortison) digunakan pada fase peradangan pada awal penyakit. Pengobatan sistemik harus dipertimbangkan pada pasien dengan skleroderma linear dan morfea generalisata atau subtipe yang dalam, karena risiko timbulnya cacat sangat besar. ${ }^{12}$ Jika penyakit tampak aktif, kortikosteroid atau metotreksat dapat diberikan. Metotreksat dengan dosis $0,5-1 \mathrm{mg} / \mathrm{kg} / \mathrm{minggu}$ merupakan obat imunosupresi yang paling sering digunakan, ${ }^{12,13}$ yang diteruskan minimal 1 tahun sesudah penyakit tidak aktif, lalu dosis mulai diturunkan.

D-penisilamin adalah salah satu obat yang banyak dipakai sebagai antifibrotik ${ }^{12}$ pada pasien karena lesi yang luas dan progresif disertai kontraktur yang berpotensi menimbulkan kecacatan. Obat ini berfungsi sebagai copper chelating agent yang menghambat grup aldehid yang terlibat dalam crosslink kolagen, ${ }^{19,21,22}$ dan dapat melunakkan kulit dan memperlambat progresivitas keterlibatan sistemik. ${ }^{19}$ Dosis inisial $3 \mathrm{mg} /$ $\mathrm{kgBB} /$ hari selama 2 bulan, dan dapat ditingkatkan 2$3 \mathrm{mg} / \mathrm{kgBB} /$ hari setiap bulan sampai dosis $10-15 \mathrm{mg} /$ $\mathrm{kgBB} / \mathrm{hari} .{ }^{4}$ Dosis rendah lebih dianjurkan karena dosis tinggi tidak terbukti memberikan hasil yang lebih baik, bahkan meningkatkan risiko timbulnya efek samping berupa depresi sumsum tulang, sindrom nefrotik, gangguan saluran cerna dan fungsi hati. ${ }^{19,21,22}$ Dosis optimal harus dipertahankan setidaknya 6 bulan dan tetap diberikan hingga 6 bulan pasca remisi. Selama pengobatan dengan D-penisilamin, kulit pasien semakin melunak dan tidak didapatkan efek samping.

Program rehabilitasi medis dilakukan secara terus 
Tabel 1. Terapi skleroderma lokal (SL) dan skleroderma sistemik (SS) ${ }^{19}$

\begin{tabular}{|c|c|c|}
\hline \multirow{3}{*}{ SL } & Morfea & Kortikosteroid (topikal dan intralesional), Kalsipotrien topikal \\
\hline & Morfea linear & $\begin{array}{l}\text { Kortikosteroid (topikal dan intralesional), Kalsipotrien topikal, kalsitriol } \\
\text { oral, PUVA dan UVA }\end{array}$ \\
\hline & Morfea generalisata & PUVA dan UVA, kalsitriol oral, MTX , MTX dan kortikosteroid \\
\hline \multirow{3}{*}{ SS } & Vasodilator & $\begin{array}{l}\text { Ca channel blockers (nifedipin), ACE inhibitors (kaptopril, losartan), } \\
\text { Prostaglandin (iloprost). }\end{array}$ \\
\hline & Imunosupresan & MTX, siklofosfamid, siklosporin, ekstrakorporeal fotoferesis. \\
\hline & Antifibrosis & D-penisilamin, kolkisin, interferon- $\gamma$, relaksin. \\
\hline
\end{tabular}

menerus untuk mempertahankan fungsi sendi dan kekuatan otot serta mencegah deformitas lebih lanjut. ${ }^{7,12}$ Pada pasien ini fleksi kontraktur dan pergerakan sendi semakin membaik dengan terapi fisik tersebut. Rekonstruksi bedah dilakukan pada pasien dengan fleksi kontraktur residual yang berlebihan pada jari tangan dan kaki. Operasi dilakukan sesudah fase aktif penyakit mereda. ${ }^{12}$

Prognosis SL tergantung pada tipe morfea, pada umumnya SL membaik secara spontan dalam 35 tahun, ${ }^{4}$ namun tetap dianjurkan pemeriksaan rutin minimal 3 bulan sekali untuk mengawasi kemungkinan timbulnya gejala sistemik. ${ }^{14}$ Anak dengan SL mempunyai harapan hidup yang normal, lesi kulit melunak $50 \%$ selama 2,7 tahun, sedangkan perubahan pigmentasi kulit akan berlangsung beberapa tahun lebih lama, namun fleksi kontraktur residual dan atrofi kulit maupun otot pada ekstremitas akan menetap., ${ }^{4,14}$ Secara umum prognosis pada pasien ini adalah quo ad vitam bonam, quo ad functionam dubia ad bonam dan quo ad sanationam dubia ad bonam.

\section{Daftar Pustaka}

1. Furst EA. Scleroderma: a fascinating, troubling disease. Diunduh dari http://www.medscape.com. Diakses tanggal 20 Juni 2006.

2. Laxer R, Seibold J, Malcarne V, Gaither K. What is juvenile scleroderma? Diunduh dari http://www.jsdn.org. Diakses tanggal 27 Juni 2006.

3. Zulian F, Cassidy JT. The systemic sclerodermas and related disorders. Dalam: Cassidy JT, Petty RE, Laxer RM, Lindsley CB, penyunting. Textbook of pediatric rheumatology. Edisi ke-5. Philadelphia: Elsevier Saunders Incorporated; 2005.h.442-71.
4. Spraker MK, Gonzales EG, Sanchez LT. Sclerosing and atrophying conditions. Dalam: Schachner LA, Hansen RC, Happle R, Krafchik BR, Lucky AW, Paller AS, Roger $\mathrm{M}$, penyunting. Pediatric dermatology. Edisi ke-3. Edinburg: Mosby; 2003. h. 769-75.

5. National Institute of Arthritis and Musculoskeletal and Skin Diseases. Handout on health: Scleroderma. Diunduh dari http://www.niams.nih.gov. Diakses tanggal 17 Juni 2006.

6. Staff Mayo Clinic. Scleroderma. Diunduh dari http:// www.MayoClinic.com. Diakses tanggal 17 Juni 2006.

7. Miller ML. Scleroderma. Dalam: Behrman RE, Kliegman RM, Jenson HB, penyunting. Nelson textbook of pediatrics. Edisi ke-17. Philadelphia: WB Saunders Company; 2004. h. 816-9.

8. Elliot T. Scleroderma, thoracic. Diunduh dari http:// www.emedicine.com. Diakses tanggal 20 Juni 2006.

9. Koenig AS. Scleroderma. Diunduh dari http:// www.medscape.com. Diakses tanggal 20 Juni 2006.

10. Ensz S. Scleroderma from A to Z. Diunduh dari http:// www.sclero.org. Diakses tanggal 17 Juni 2006.

11. Connoly MK. Scleroderma. Dermatologic therapy 2001;14:81-94.

12. Nelson AM, Laxer RM. Localized sclerodermas. Dalam: Cassidy JT, Petty RE, Laxer RM, Lindsley CB, penyunting. Textbook of pediatric rheumatology. Edisi ke-5. Philadelphia: Elsevier Saunders Incorporated; 2005. h. 472-81.

13. Zulian F, Athreya BH, Laxer R, Nelson AM, Oliviera SKF, Punaro MFdkk. Juvenile scleroderma: clinical and epidemiological features in 750 children. An international study. Rheumatol 2006;45:614-20.

14. Weston WL, Lane AT, Morelli JG. Immobile and hypermobile skin. Dalam: Weston WL, Lane AT, Morelli JG, penyunting. Color textbook of pediatric dermatology. Edisi ke-3. St Louis, Missouri: Mosby, Inc.; 2002. 
h. 264-6.

15. Morrow J, Nelson JL, Watts R, Isenberg D. Scleroderma. Dalam: Morrow J, Nelson JL, Watts R, Isenberg D, penyunting. Autoimmune rheumatic disease. Edisi ke-2. New York: Oxford University Press; 1999. h. 194-215.

16. Tu JH, Eisen AZ. Scleroderma. Dalam: Freedberg IM, Eisen AZ, Wolff K, Austen KF, Goldsmith LA, Katz SI, Fitzpatrick TB, penyunting. Fitzpatrick's dermatology in general medicine. Edisi ke-5. New York: McGrawHill; 1999. h. 2023-33.

17. Athreya BH. Laboratory tests in juvenile scleroderma. Diunduh dari http://www.jsdn.org. Diakses tanggal 27 Juni 2006.
18. Silver R. Lung fibrosis in systemic sclerosis. Scleroderma voice 2004;1:4-8.

19. Sapadin AN, Fleischmajer R. Treatment of scleroderma. Arch Dermatol 2002;138:99-105.

20. Haustein UF. Systemic sclerosis-scleroderma. Diunduh dari http://www. dermatology.cdlib.org. Diakses tanggal 20 Juni 2006.

21. Falanga V, Medsger TA. D-penicillamine in the treatment of localized scleroderma. Arch Dermatol 1990;126:609-12.

22. Weller C. Your medications : a guide to better understanding. Diunduh dari www.scleroderma.org. Diakses tanggal 17 Juni 2006. 